Review

\title{
Applications of Shell-Isolated Nanoparticle-Enhanced Raman Spectroscopy
}

\author{
Grégory Barbillon
}

Citation: Barbillon, G. Applications of Shell-Isolated NanoparticleEnhanced Raman Spectroscopy. Photonics 2021, 8, 46. https:// doi.org/10.3390/photonics8020046

Received: 1 January 2021 Accepted: 9 February 2021 Published: 12 February 2021

Publisher's Note: MDPI stays neutral with regard to jurisdictional clai$\mathrm{ms}$ in published maps and institutional affiliations.

Copyright: (C) 2021 by the author. Licensee MDPI, Basel, Switzerland. This article is an open access article distributed under the terms and conditions of the Creative Commons Attribution (CC BY) license (https:// creativecommons.org/licenses/by/ $4.0 /)$.
EPF-Ecole d'Ingénieurs, 92330 Sceaux, France; gregory.barbillon@epf.fr

\begin{abstract}
The surface-enhanced Raman scattering (SERS) is mainly used as an analysis or detection tool of biological and chemical molecules. Since the last decade, an alternative branch of the SERS effect has been explored, and named shell-isolated nanoparticle Raman spectroscopy (SHINERS) which was discovered in 2010. In SHINERS, plasmonic cores are used for enhancing the Raman signal of molecules, and a very thin shell of silica is generally employed for improving the thermal and chemical stability of plasmonic cores that is of great interest in the specific case of catalytic reactions under difficult conditions. Moreover, thanks to its great surface sensitivity, SHINERS can enable the investigation at liquid-solid interfaces. In last two years (2019-2020), recent insights in this alternative SERS field were reported. Thus, this mini-review is centered on the applications of shell-isolated nanoparticle Raman spectroscopy to the reactions with CO molecules, other surface catalytic reactions, and the detection of molecules and ions.
\end{abstract}

Keywords: SHINERS; SERS; core-shell nanoparticles; catalysis; electrochemistry; plasmonics

\section{Introduction}

Over the past ten years, the realization of plasmonic structures with a very high sensitivity of detection has significantly increased for application to surface-enhanced spectroscopies [1-10]. Among these enhanced spectroscopies, we find the surface-enhanced Raman scattering (SERS), which uses the plasmonic nanostructures or nanoparticles for amplifying the Raman signal of various molecules. For this amplification, a huge number of geometries has been examined as plasmonic nanodimers [11-15], nanorods [16-20], nanotriangles [21-25] and nanostars [26-30]. Furthermore, plasmonic nanopores have been explored in order to improve the SERS enhancement [31-34]. In addition, another type of SERS substrates has been investigated consisting of a metallic mirror on which plasmonic nanoparticles or nanostructures were deposited or fabricated allowing an enhancement of 1 or 2 magnitude orders due to hybridized modes or a coupling between nanoparticles or nanostructures via surface plasmon polaritons on the metallic mirror (film) [35-39]. Another way to improve the Raman signal was the use of hybrid nanomaterials based on zinc oxide or silicon coupled to a plasmonic layer or plasmonic nanoparticles [40-49], and also based on bimetallic nanoparticles [50-55] or other materials as metal oxides [56-61]. Another branches of the SERS field have been also explored, such as the photo-induced enhanced Raman spectroscopy [62-64], the SERS effect generated by high pressure [65,66], and the shell-isolated nanoparticle-enhanced Raman spectroscopy (SHINERS) [67-69]. Concerning SHINERS, this technique has been discovered in 2010 in order to overcome the limitations of SERS regarding the accurate characterization of different surface morphologies, materials, and biological samples [67]. The base concept of SHINERS consists of plasmonic cores that are employed for enhancing the Raman signal of molecules, and a very thin shell of silica improving the thermal and chemical stability of the plasmonic cores, being of significant interest in the specific case of catalytic reactions under difficult conditions $[70,71]$. By using SHINERS, several groups have already studied catalytic reactions [72-74], applications in electrochemistry [75], and also reported the detection of different chemical molecules [76-81]. 
The goal of this mini-review is to present the recent advances on the most used applications of SHINERS, such as the catalytic reaction-monitoring processes and the detection of molecules, over the period 2019-2020. Firstly, we will explore the SHINERS applications to the reactions with $\mathrm{CO}$ molecules, which are well-known model reactions, then other surface catalytic reactions, and finally the detection of molecules and ions in order to examine the potential of this SHINERS technique. In the final section, we will discuss points to be improved and advantages of the SHINERS technique, and we will address the future directions of this latter.

\section{What Is Shell-Isolated Nanoparticle-Enhanced Raman Spectroscopy?}

The shell-isolated nanoparticle-enhanced Raman spectroscopy belongs to the SERS field, and is based on the enhancement of the Raman signal obtained with strong electric fields coming from plasmonic core-shell nanoparticles. In SHINERS, each core-shell nanoparticle plays the role of a metallic tip as for the tip-enhanced Raman spectroscopy (TERS), and this technique allows to obtain a couple of thousand of "TERS tips" on the substrate surface to be analyzed. Thus, the enhanced Raman signal can be jointly obtained from all these plasmonic core-shell nanoparticles ("TERS tips"), allowing a gain of two to three magnitude orders compared to a single TERS tip. Furthermore, the use of the metallic nanoparticles coated with a chemically inert shell can enable the protection of the plasmonic core (SERS-active part) from the substrate surface to be analyzed and the environment. This inert shell can conform to different morphologies of substrates, and also prevent the agglomeration of these core-shell nanoparticles and the oxidation of their plasmonic core. The principal merits of such a technique are a more significant detection sensitivity and a great number of practical applications in life and materials sciences, as well as in food science and environmental pollution.

\section{Applications of Shell-Isolated Nanoparticle-Enhanced Raman Spectroscopy}

\subsection{SHINERS Application to the Reactions with CO Molecules}

In this section, we present a couple of investigations on the reactions with $\mathrm{CO}$ molecules (see Table 1) [82-86]. These reactions with $\mathrm{CO}$ molecules are well-known model reactions.

Table 1. Shell-isolated nanoparticle Raman spectroscopy (SHINERS) application to the reactions with $\mathrm{CO}$ molecules (NPs = nanoparticles; $\mathrm{G}=$ Graphene).

\begin{tabular}{cccc}
\hline Samples & Core/Shell Size (nm) & Reaction & Refs \\
\hline $\mathrm{PtFe} / \mathrm{Au} @ \mathrm{SiO}_{2} \mathrm{NPs}$ & $120 / 2$ & CO oxidation & {$[82]$} \\
$\mathrm{Pt} / \mathrm{Au} @ \mathrm{SiO}_{2} \mathrm{NPs}$ & $55 / 2$ & CO electrooxidation & {$[83]$} \\
$\mathrm{Pt} / \mathrm{Au} @ \mathrm{SiO}_{2} \mathrm{NPs}$ & $101 / 2$ & CO adsorption & {$[84]$} \\
$\mathrm{Ni} / \mathrm{Au} @ \mathrm{SiO}_{2} \mathrm{NPs}$ & $90 / 2$ & $\mathrm{CO}$ adsorption & {$[85]$} \\
$\mathrm{Au} @ \mathrm{SiO} \mathrm{NPs}_{2} \mathrm{NPu} \mathrm{AiO}_{2} \mathrm{NPs}$ & $90 / 3-105 / 2$ & Hydrogenation/dissociation of $\mathrm{CO}$ & {$[86]$} \\
$\mathrm{Pt} / \mathrm{Au} @ \mathrm{G} \mathrm{NPs}$ & $500 / 5$ layers of G & CO adsorption & {$[87]$} \\
$\mathrm{Au} @ \mathrm{SiO}_{2} \mathrm{NPs}$ on $\mathrm{Cu}$ foil & $50 / 2$ & CO adsorption & {$[88,89]$} \\
\hline
\end{tabular}

Wang et al., have reported on the $\mathrm{CO}$ oxidation probed SHINERS technique based on the use of $\mathrm{Au} @ \mathrm{SiO}_{2}$ nanoparticles, on which are deposited Pt or PtFe nanocatalysts (see Figure 1a) [82]. The authors demonstrated that PtFe catalysts were more active and stable than $\mathrm{Pt}$ ones in the $\mathrm{CO}$ oxidation. In the $\mathrm{CO}$ oxidation, two Raman peaks have been observed at 397 and $485 \mathrm{~cm}^{-1}$ for Pt catalysts and at 389 and $480 \mathrm{~cm}^{-1}$ for PtFe catalysts, both corresponding to the adsorption of Pt-CO (see Figure 1b). The redshift of these two Raman peaks recorded for the case with PtFe catalysts has indicated that the $\mathrm{CO}$ adsorption was lower on PtFe than on Pt (see the inset of Figure 1b). Moreover, three Raman peaks of oxygen species were detected with PtFe nanocatalysts, indicating that the Pt-C binding 
was weakened by the presence of the ferrous center thus producing oxygen species (see Figure 1b) [82].

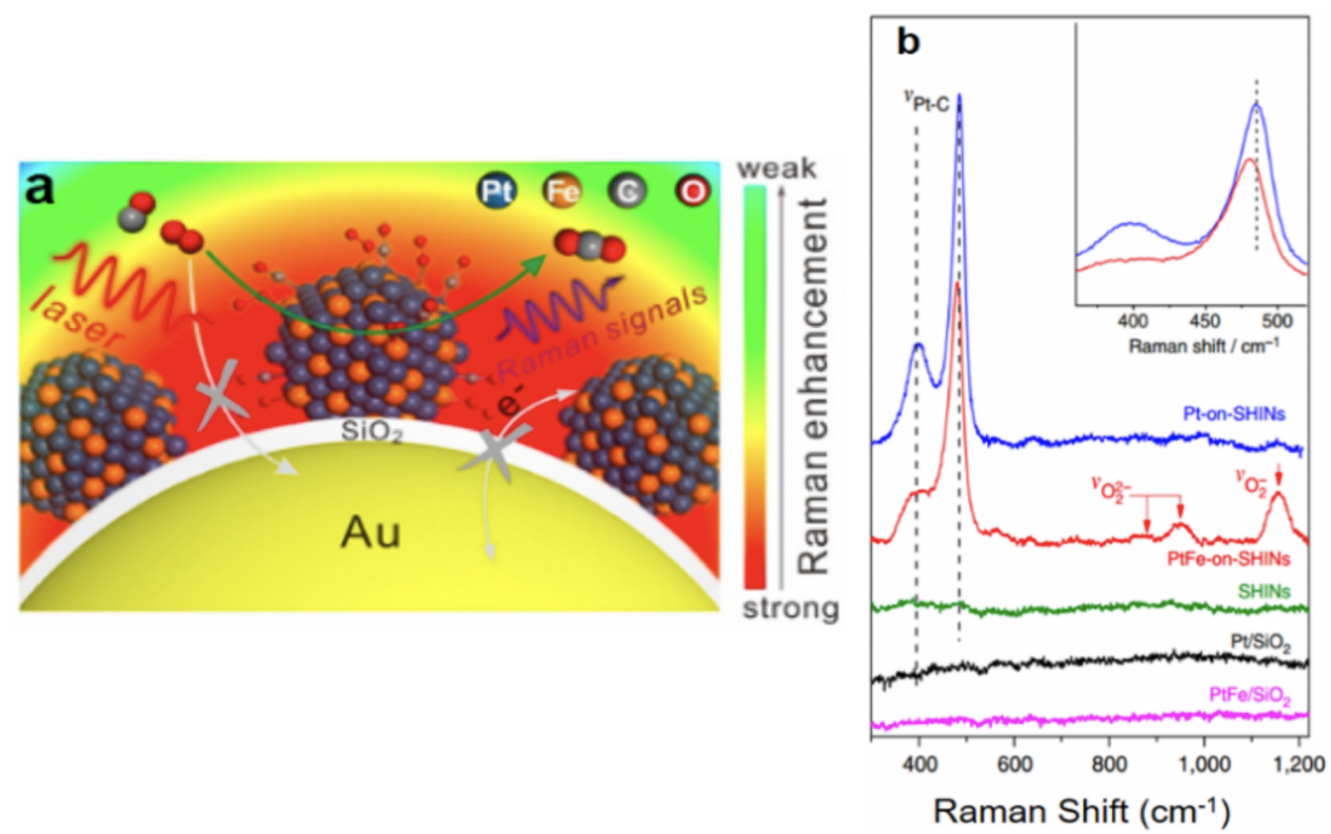

Figure 1. (a) Principle scheme of a SHINERS catalyst $\left(\mathrm{PtFe} / \mathrm{Au} @ \mathrm{SiO}_{2}\right)$ for $\mathrm{CO}$ oxidation. (b) SHINERS spectra for CO oxidation on Pt (blue line) and PtFe (red line) catalysts. The inset displays a zoom of the two SHINERS spectra (blue and red lines) in the range $350-550 \mathrm{~cm}^{-1}$ in order to better observe the redshift of Raman peaks. All the figures are reprinted (adapted) with permission from [82], Copyright 2019 American Chemical Society.

$\mathrm{Su}$ et al., have reported on the detection of $\mathrm{OH}$ and $\mathrm{COOH}$ species during the $\mathrm{CO}$ electrooxidation process on three Pt surfaces $(\mathrm{Pt}(100), \mathrm{Pt}(110)$ and $\mathrm{Pt}(111))$ with the SHINERS technique by using $\mathrm{Au} @ \mathrm{SiO}_{2}$ nanoparticles [83]. The authors have observed that the activity of $\mathrm{CO}$ electrooxidation was higher for $\mathrm{Pt}(111) / \mathrm{Pt}(100)$ surfaces than $\mathrm{Pt}(110)$ surface. This increased activity of CO electrooxidation for $\mathrm{Pt}(111) / \mathrm{Pt}(100)$ surfaces was due to the presence of $\mathrm{OH}$ and $\mathrm{COOH}$ species. For $\mathrm{Pt}(110)$ surface, this activity was weaker due to its high adsorption and coverage of $\mathrm{CO}$ on this surface [83]. Furthermore, Wondergem et al. have demonstrated the $\mathrm{CO}$ adsorption on Pt nanoparticles which are themselves deposited on $\mathrm{Au} @ \mathrm{SiO}_{2}$ nanoparticles (see Figure 2a,b) [84]. This investigation was realized by employing the SHINERS technique. From the SHINERS spectra, two characteristic Raman peaks of $\mathrm{CO}$ adsorption were recorded in the two ranges of wavenumbers: $350-600 \mathrm{~cm}^{-1}$ and $1900-2150 \mathrm{~cm}^{-1}$. The first Raman peak corresponds to the CO adsorbed on $\mathrm{Pt}$ in a bridge configuration located at 430 and $2010 \mathrm{~cm}^{-1}$ in these two ranges of wavenumbers (see Figure 2c,d), then the second one corresponds to the $\mathrm{CO}$ adsorbed on $\mathrm{Pt}$ in a linear configuration located at 505 and $2070 \mathrm{~cm}^{-1}$ in these two wavenumber ranges (see Figure 2c,d) [84]. Next, the same group has studied the effect of the fabrication method of nickel (Ni) catalysts on $\mathrm{Au} @ \mathrm{SiO}_{2}$ nanoparticles for SHINERS investigations [85]. Three methods have been tested: spark ablation (SA), colloidal deposition (Col) and precusor (Pr) method. The authors have studied the CO adsorption on these three types of Ni catalysts, and concluded that Pr and Col methods were not suitable for the SHINERS technique due to the use of a high-temperature treatment of reduction. Finally, the SA technique is the most efficient for direct deposition of the nickel catalyst on $\mathrm{Au} @ \mathrm{SiO}_{2}$ nanoparticles [85]. 

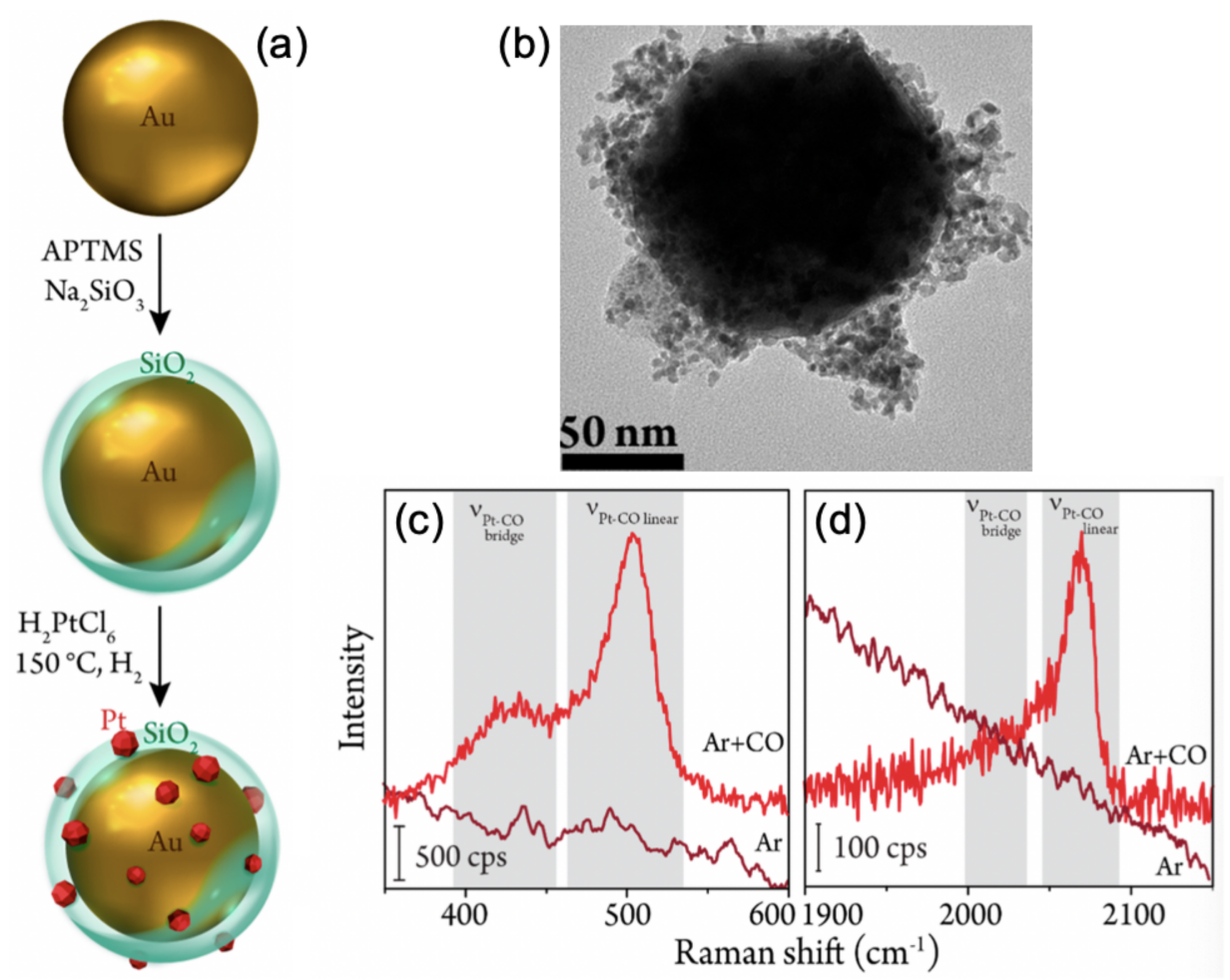

Figure 2. (a) Fabrication process of a SHINERS catalyst $\left(\mathrm{Pt} / \mathrm{Au} @ \mathrm{SiO}_{2}\right)$. (b) $\mathrm{TEM}$ picture of a SHINERS catalyst (Pt/Au@SiO ${ }_{2}$ ). SHINERS spectra for $\mathrm{CO}$ adsorption on $\mathrm{Pt}$ for $(\mathbf{c})$ the low range of wavenumbers and (d) the high range of wavenumbers. The grey zones correspond to the Raman peaks of Pt-CO bridge at 430 and $2010 \mathrm{~cm}^{-1}$, and Pt-CO linear at 505 and $2070 \mathrm{~cm}^{-1}$. All the figures are reprinted (adapted) with permission from [84] (https:/ / pubs.acs.org/doi/10.1021/acscatal.9b03010 (accessed on 1 January 2021)), Copyright 2019 American Chemical Society (for all further reuses related to the excerpted material, further permissions should be directed to the American Chemical Society).

Hartman et al. have investigated the support effect on the interaction of rhodium (Rh) with CO molecules probed by SHINERS technique [86]. Two types of extrudate support have been tested by introducing alternatively $\mathrm{CO}$ and $\mathrm{H}_{2}$ : the first one was $\mathrm{Rh} / \mathrm{SiO}_{2}$ on which were deposited $\mathrm{Au} @ \mathrm{SiO}_{2}$ nanoparticles and the second one was $\mathrm{Rh} / \mathrm{TiO}_{2}$ on which were also deposited $\mathrm{Au} @ \mathrm{TiO}_{2}$ nanoparticles. Under the same conditions of $\mathrm{CO}$ then $\mathrm{H}_{2}$, the shifts of a Raman peak (named "unknown" by the authors) for the $\mathrm{CO}$ hydrogenation were of $70 \mathrm{~cm}^{-1}$ and $25 \mathrm{~cm}^{-1}$ for $\mathrm{Rh} / \mathrm{TiO}_{2}$ and $\mathrm{Rh} / \mathrm{SiO}_{2}$ extrudate supports, respectively. From these Raman shifts for the $\mathrm{CO}$ hydrogenation, the authors have deduced that the $\mathrm{Rh} / \mathrm{TiO}_{2}$ extrudate support had the strongest interaction with $\mathrm{CO}$ molecules during the catalytic process compared to the $\mathrm{Rh} / \mathrm{SiO}_{2}$ extrudate support. Thus, this powerful interaction has resulted in a catalyst with higher efficiency for the CO dissociation [86]. Zhang et al., have reported on the adsorption of CO molecules on Pt nanocatalysts, which were deposited on novel core-shell nanoparticles composed of a gold core covered by graphene layers (Au@G nanoparticles). The authors have demonstrated via SHINERS measurements that the adsorption of CO molecules on these Pt/Au@G nanoparticles has occurred in a linear configuration [87]. To finish this section, two groups have reported on the $\mathrm{CO}$ reduction catalysis on $\mathrm{Cu}$ foil by using the SHINERS technique $[88,89]$. The authors have employed $\mathrm{Au} @ \mathrm{SiO}_{2}$ nanoparticles, and allowed them to deduce that the $\mathrm{CuO}_{x} /(\mathrm{OH})_{y}$ species were detected on the $\mathrm{Cu}$ foil during the $\mathrm{CO}$ reduction. Thus, the authors have concluded that the oxygenated species of $\mathrm{Cu}$ were unlikely to be the active sites easing the formation of $\mathrm{C}_{2+}$ oxygenates during the process of $\mathrm{CO}$ reduction $[88,89]$. 


\subsection{SHINERS Application to Other Surface Catalytic Reactions}

Here, we address a couple of studies on other surface catalytic reactions (see Table 2) [90-100].

Table 2. SHINERS application to other surface catalytic reactions (NPs $=$ nanoparticles; $\operatorname{IrO} \mathrm{O}_{x}=$ Iridium oxide; $\mathrm{MBT}=2$-mercaptobenzothiazole; $\mathrm{SnO}_{2}=$ Tin oxide; $\mathrm{pNTP}$ = para-nitrothiophenol; $\mathrm{RhB}=$ Rhodamine $\mathrm{B} ; \mathrm{CNNDs}=\mathrm{g}-\mathrm{C}_{3} \mathrm{~N}_{4}$ nanodots; EGLs = Electrochemical exfoliated graphene layers; $\mathrm{ITO}=$ Indium tin oxide).

\begin{tabular}{cccc}
\hline Samples & Core/Shell Size (nm) & Reaction & Refs \\
\hline $\mathrm{Au} @ \mathrm{SiO}_{2} \mathrm{NPs} / \mathrm{Pt}$ & $90 / 2$ & Adsorption of Propargyl Alcohol & {$[90]$} \\
$\mathrm{Au} @ \mathrm{SiO}_{2} \mathrm{NPs}_{\mathrm{IrO}}$ surface & $55 / 2$ & Water oxidation & {$[91]$} \\
$\mathrm{Au} @ \mathrm{SiO}_{2} \mathrm{NPs} / \mathrm{Au}(111)$ & $55 / 2$ & Configuration of interfacial water & {$[92]$} \\
$\mathrm{Au} @ \mathrm{SiO}_{2} \mathrm{NPs} /$ pyrite & $55 / 2$ & Adsorption of MBT & {$[93]$} \\
$\mathrm{Au} @ \mathrm{SiO}_{2} \mathrm{NPs} / \mathrm{Cu}$ surface & $55 / 2$ & Oxidation of $\mathrm{Cu}$ surfaces & {$[94]$} \\
$\mathrm{Au} @ \mathrm{SiO}_{2} \mathrm{NPs} / \mathrm{Pt}(h k l)$ & $55 / 2-3$ & Oxygen reduction reaction & {$[95]$} \\
$\mathrm{Au} @ \mathrm{SiO}_{2} \mathrm{NPs} / \mathrm{Pt}(h k l)$ & $55 / 2$ & Oxygen reduction reaction & {$[96]$} \\
$\mathrm{Au} @ \mathrm{SiO}_{2} \mathrm{NPs} / \mathrm{Pt}(h k l)$ & $55 / 2$ & Oxygen reduction reaction & {$[97]$} \\
$\mathrm{Au} @ \mathrm{SnO}_{2} \mathrm{NPs} / \mathrm{steel} \mathrm{surface}$ & $35 / 4$ & Steel surface corrosion & {$[98]$} \\
$\mathrm{Pt}_{\mathrm{Au} @ S i \mathrm{~A}_{2} \mathrm{NPs}}$ & $120 / 2$ & Hydrogenation of pNTP & {$[99]$} \\
$\mathrm{Ag} @ S i \mathrm{O}_{2} / \mathrm{RhB} / \mathrm{CNND} / \mathrm{EGL} / \mathrm{ITO}$ & $75 / 3$ & Photodegradation of RhB & {$[100]$} \\
\hline
\end{tabular}

Guan et al. have demonstrated that the adsorption of propargyl alcohol (PA) on $\mathrm{Pt}(h k l)$ surfaces by using the SHINERS technique [90]. The authors have employed $\mathrm{Au} @ \mathrm{SiO}_{2}$ nanoparticles for SHINERS experiments, and they obtained adsorption of PA-privileged on $\operatorname{Pt}(100)$ and $\operatorname{Pt}(110)$ surfaces than on $\operatorname{Pt}(111)$ surface. The better surface reactivity for $\mathrm{Pt}(100)$ compared to two other $\mathrm{Pt}$ surfaces $(\mathrm{Pt}(100)>\mathrm{Pt}(110)>\mathrm{Pt}(111))$ was due to the more important presence of the primary alcohol group [90]. In the next two examples, the studies of the water oxidation and the configuration of the interfacial water are addressed. Firstly, Saeed et al., have reported on the employment of the SHINERS technique to analyze in realtime the mechanisms of water oxidation with iridium oxides $\left(\mathrm{IrO}_{x}\right)$ as electrocatalyst [91]. To do that, $\mathrm{Au} @ \mathrm{SiO}_{2}$ nanoparticles were used and deposited on $\mathrm{IrO}_{x}$ surface for the Raman characterization (SHINERS). Thus, the authors demonstrated that SHINERS allowed to observe in real-time the chemical changes on the $\mathrm{IrO}_{x}$ surface during the oxidation of water [91]. Secondly, $\mathrm{Li}$ et al., have reported on the configuration of the interfacial water at $\mathrm{Au}(111)$ surface, probed by the SHINERS technique using $\mathrm{Au} @ \mathrm{SiO}_{2}$ nanoparticles for this study [92]. The authors have observed redshifts of the Raman peak corresponding to the $\mathrm{O}-\mathrm{H}$ stretching mode of the interfacial water when the potential went towards more negative values, indicating a configuration variation of interfacial water. Thus, the authors have shown three configurations of the interfacial water named parallel, one-H-down and two-H-down, respectively, when the potential shifted to more negative values [92]. In addition, Guo et al., have studied the adsorption of 2-mercaptobenzothiazole (MBT) on pyrite by SHINERS [93]. Au@SiO 2 nanoparticles were employed and deposited on pyrite for SHINERS experiments. From the SHINERS spectra recorded with an MBT concentration of $0.01 \mathrm{mM}$, a Raman peak at $1406 \mathrm{~cm}^{-1}$ was observed and corresponded to NCS ring stretch mode (see Figure 3a). This Raman peak suggested that double "minerophilic" groups of MBT were bound to pyrite surfaces in the configuration displayed in Figure $3 \mathrm{~b}$ on the left. From the SHINERS spectra recorded with an MBT concentration of $0.1 \mathrm{mM}$, two Raman peaks at 1389 and $1409 \mathrm{~cm}^{-1}$ were observed and also corresponded to NCS ring stretch mode (see Figure 3c). The Raman peak at $1409 \mathrm{~cm}^{-1}$ has indicated that double "minerophilic" groups of MBT were bound to pyrite surface. The Raman peak at $1389 \mathrm{~cm}^{-1}$ (starting to appear at $-200 \mathrm{mV}$, see Figure 3c) has also indicated that the MBT molecule was bound to pyrite with the exocyclic sulfur atom without the presence of any nitrogen-metal bond in the configuration displayed in Figure $3 \mathrm{~b}$ on the right. In summary, the authors 
have concluded that the configuration of MBT molecules was preferentially the one in Figure $3 b$ on the left for weaker concentrations of MBT and negative potentials and the one in Figure $3 b$ on the right for higher concentrations of MBT and positive potentials [93].
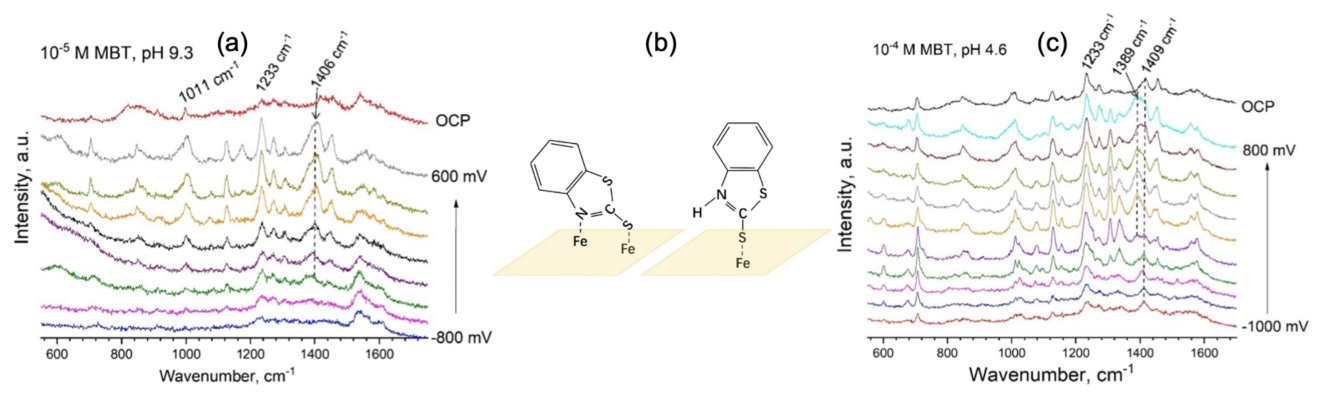

Figure 3. (a) SHINERS spectra of a MBT solution $(0.01 \mathrm{mM})$ recorded at $\mathrm{pH} 9.3$ for different potentials. The black dotted line indicates the Raman peak at $1406 \mathrm{~cm}^{-1}$. (b) Potential configurations of the MBT adsorption on pyrite. (c) SHINERS spectra of a MBT solution $(0.1 \mathrm{mM})$ recorded at $\mathrm{pH} 4.6$ for different potentials. The black dotted lines indicate the Raman peaks at 1389 and $1409 \mathrm{~cm}^{-1}$. All the figures are reprinted from [93], Copyright 2020, with permission from Elsevier.

Bodappa et al., have investigated the electrochemical oxidation of $\mathrm{Cu}(111)$ and polycrystalline $\mathrm{Cu}\left(\mathrm{Cu}\right.$ (poly)) surfaces by using the SHINERS technique [94]. Au@SiO ${ }_{2}$ nanoparticles were employed for studying the oxidation mechanism of $\mathrm{Cu}(111)$ and $\mathrm{Cu}($ poly) surfaces (see Figure 4a). From the SHINERS spectra for $\mathrm{Cu}(111)$ oxidation, intermediate species $\mathrm{Cu}-\mathrm{OH}, \mathrm{Cu}-\mathrm{O}_{a d}$, and $\left(\mathrm{Cu}_{2} \mathrm{O}\right)_{\text {surf }}$ were observed during the oxidation process (i.e., when the potential increased, see Figure $4 \mathrm{~b}$ ). For $\mathrm{Cu}$ (poly) oxidation, only $\mathrm{Cu}-\mathrm{OH}$ and $\left(\mathrm{Cu}_{2} \mathrm{O}\right)_{\text {surf }}$ were spotted during the oxidation on the SHINERS spectra (see Figure $4 \mathrm{c}$ ). Thus, the authors have remarked a difference in the presence of the intermediate species during the oxidation process [94].

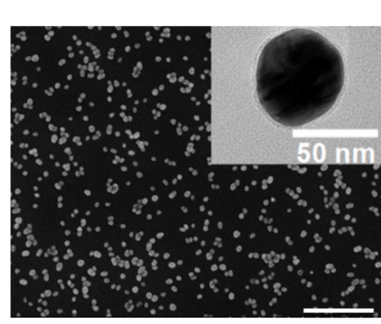

(a)
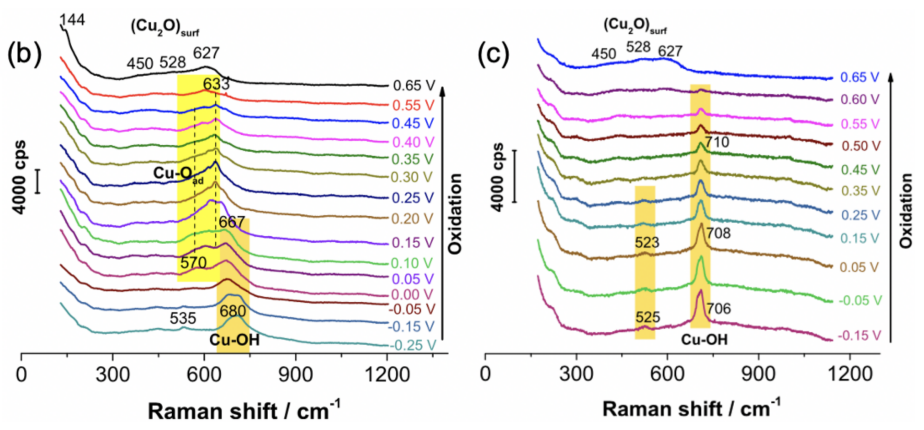

Figure 4. (a) SEM picture of $\mathrm{Au} @ \mathrm{SiO}_{2}$ nanoparticles on $\mathrm{Cu}$ surface (scale bar $=1 \mu \mathrm{m}$ ). The inset displays a TEM picture of a $\mathrm{Au} @ \mathrm{SiO}_{2}$ nanoparticle. (b) SHINERS spectra for $\mathrm{Cu}(111)$ oxidation in a $0.01 \mathrm{M} \mathrm{KOH}$ solution. (c) SHINERS spectra for $\mathrm{Cu}$ (poly) oxidation in a $0.01 \mathrm{M} \mathrm{KOH}$ solution. All the figures are reprinted (adapted) with permission from [94], Copyright 2019 American Chemical Society.

The next three works have addressed the topic of oxygen reduction reaction (ORR) on $\mathrm{Pt}(h k l)$ surfaces by employing SHINERS spectroscopy. At first, Galloway et al., have demonstrated the surface specificity of the ORR on $\mathrm{Pt}(h k l)$ surfaces by SHINERS in sodiumoxygen electrochemistry [95]. The reduction of $\mathrm{NaO}_{2}$ to $\mathrm{Na}_{2} \mathrm{O}_{2}$ was favored on $\mathrm{Pt}(111)$ and $\mathrm{Pt}(110)$ surfaces in $0.1 \mathrm{M} \mathrm{NaClO}_{4}$ dissolved in dimethyl sulfoxide (DMSO), whereas this reduction was not detected on $\mathrm{Pt}(100)$ and $\mathrm{Pt}$ (poly) surfaces (no characteristic Raman peak of $\mathrm{Na}_{2} \mathrm{O}_{2}$ recorded) due to the restricted interactions with adsorbed oxygens [95]. Next, the second work realized by Dong et al. dealt with the observation of intermediate species for ORR on different $\mathrm{Pt}(h k l)$ surfaces examined by SHINERS. The authors have 
spectroscopically evidenced the fact that ORRs on $\mathrm{Pt}(111)$ surface was obtained by the generation of $\mathrm{OOH}$ species, while for $\mathrm{Pt}(110)$ and $\mathrm{Pt}(100)$ surfaces by the formation of $\mathrm{OH}$ species [96]. Finally, the same group has demonstrated the presence of intermediate species during ORR on high-index $\mathrm{Pt}(h k l)$ surfaces by SHINERS spectroscopy [97]. $\mathrm{Au} @ \mathrm{SiO}_{2}$ nanoparticles were used for the study of the ORR activity of these Pt surfaces (see Figure 5a). The authors have observed intermediate species for the two Pt surfaces $(\mathrm{Pt}(311)$ and $\mathrm{Pt}(211))$ studied for ORR. From SHINERS spectra recorded for different values of potential, two characteristic Raman peaks at $\sim 765$ and $\sim 1041 \mathrm{~cm}^{-1}$ were observed and corresponded to $\mathrm{OOH}$ and $\mathrm{OH}$ species, respectively (see Figure $5 b, c)$. Moreover, they concluded that the $\mathrm{Pt}$ (211) surface had a better reactivity than the $\mathrm{Pt}(311)$ surface due to the greater adsorption energy for $\mathrm{OOH}$ species with the $\mathrm{Pt}(311)$ surface [97].

(a)

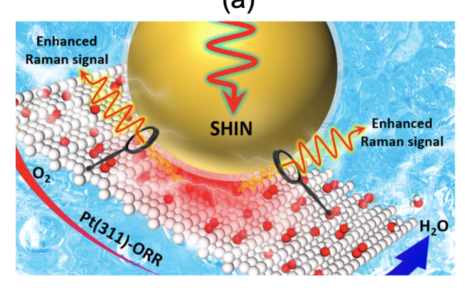

(b)

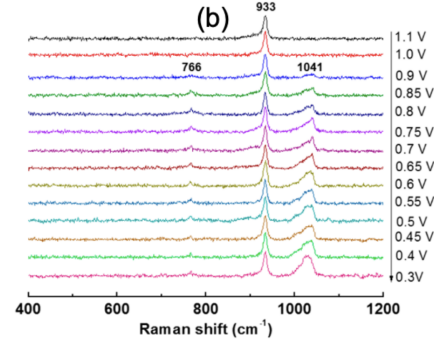

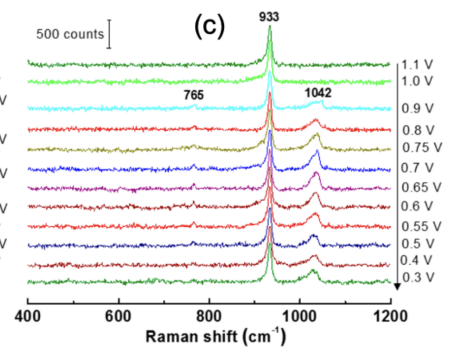

Figure 5. (a) Principle scheme of a SHINERS $\left(\mathrm{Au} @ \mathrm{SiO}_{2}\right)$ measurement for oxygen reduction reaction on $\mathrm{Pt}(h k l)$ surfaces. For different values of potential, SHINERS spectra recorded in $\mathrm{HClO}_{4}$ solution $(0.1 \mathrm{M})$ saturated in $\mathrm{O}_{2}$ are shown for the surfaces of $(\mathbf{b}) \mathrm{Pt}(311)$ and $(\mathbf{c}) \mathrm{Pt}(211)$. All the figures are reprinted (adapted) with permission from [97], Copyright 2020 American Chemical Society.

Barlow et al. have investigated the corrosion of 304 stainless steel by using the SHINERS technique. Au@SnO ${ }_{2}$ nanoparticles were employed for examining this possible corrosion [98]. For the 304 stainless steel, the authors have evidenced a characteristic Raman (SHINERS) peak corresponding to amorphous $\mathrm{Fe}(\mathrm{OH})_{2}$, and also another Raman peak attributed to $\mathrm{Cr}(\mathrm{VI})-\mathrm{O}$ bindings from a blended oxide based on $\mathrm{Cr}(\mathrm{VI})$. When $\mathrm{KCl}$ is present in the electrolyte, a Raman peak attributed to $\gamma$-FeOOH was observed. Finally, the authors have evidenced no green rust, i.e., no intermediate species during the conversion from $\mathrm{Fe}(\mathrm{OH})_{2}$ to $\gamma$-FeOOH [98]. Besides, Wang et al., have reported on the effects of the size and the nature of nanocatalysts on the hydrogenation of para-nitrothiophenol (pNTP) by employing the SHINERS spectroscopy [99]. Au@SiO $\mathrm{S}_{2}$ nanoparticles were used for SHINERS experiments on which $\mathrm{Pt}, \mathrm{PtCu}$, PtNi nanocatalysts have been assembled via electrostatic interactions. At first, the authors have studied the size effect of Pt nanocatalysts on the pNTP hydrogenation, and have reported on an optimal size of $6.8 \mathrm{~nm}$ for Pt nanoparticles. Then, the authors have studied the kinetics of reaction for $\mathrm{Pt}, \mathrm{PtCu}$ and $\mathrm{PtNi}$ nanocatalysts. They observed that $\mathrm{PtCu}$ and $\mathrm{PtNi}$ nanocatalysts have shown a quicker and quasi-complete conversion of pNTP than for Pt ones [99]. To finish this section on SHINERS applications to other surface catalytic reactions, Qiu et al. have investigated the effect of the presence of $\mathrm{g}-\mathrm{C}_{3} \mathrm{~N}_{4}$ nanodots (CNNDs) and electrochemical exfoliated graphene layers (EGLs) on the photodegradation of Rhodamine $\mathrm{B}(\mathrm{RhB})$ molecules probed by SHINERS technique [100]. For SHINERS experiments, Ag@SiO ${ }_{2}$ nanoparticles and an illumination wavelength of $632.8 \mathrm{~nm}$ were employed for examining this photocatalytic process of degradation of RhB molecules (see Figure 6a). In the absence of CNNDs and EGLs on the ITO substrate, the authors have noted no significant degradation of the intensity of the Raman peaks of RhB molecules. In contrast, the authors have observed a complete degradation of the intensity of these Raman peaks for an illumination time of 20 min with the presence of CNNDs and EGLs (see Figure 6b) [100]. 
(a)

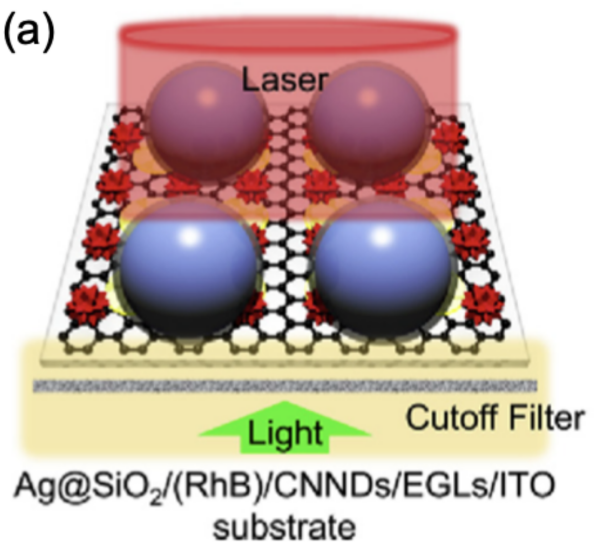

(b)

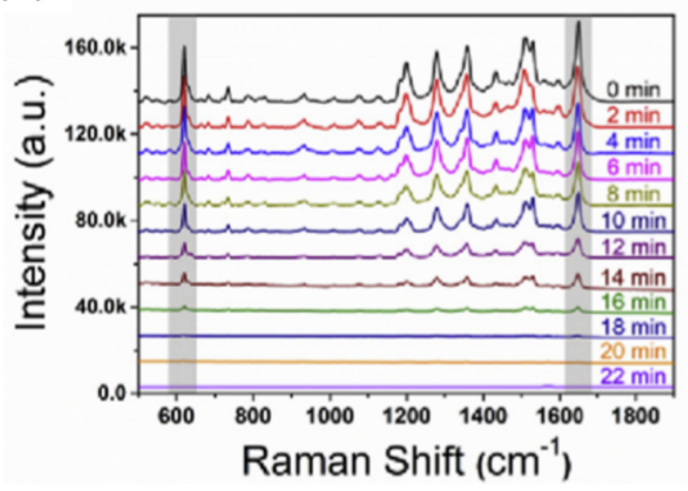

Figure 6. (a) Principle scheme for the photocatalytic process of degradation of $\mathrm{RhB}$ molecules $(\mathrm{RhB}=$ red shapes) probed by SHINERS ( $\mathrm{Ag} @ \mathrm{SiO}_{2} \mathrm{NPs}=$ blue spheres with a grey shell). The yellow shapes correspond to the $\mathrm{g}-\mathrm{C}_{3} \mathrm{~N}_{4}$ nanodots (CNNDs), and the EGLs/ITO substrate is represented by the white rectangle on which the hexagonal lattice of graphene (EGLs) is depicted. (b) SHINERS spectra of $\mathrm{RhB}$ molecules recorded for various illumination times in the range $0-22 \mathrm{~min}$. All the figures are reprinted from [100], Copyright 2019, with permission from Elsevier.

\subsection{SHINERS Application for the Detection of Molecules and Ions}

In this final section for the SHINERS applications, we report on a couple of works on the detection of molecules and ions (see Table 3) [101-107].

Table 3. SHINERS application for the detection of molecules and ions (NPs = nanoparticles; $c c-A u=$ concave cubic gold; PPy = Polypyrrole).

\begin{tabular}{|c|c|c|c|}
\hline Samples & Core/Shell Size (nm) & Detection & Refs \\
\hline$\left(\mathrm{Au} / \mathrm{SiO}_{2}\right) @ \mathrm{SiO}_{2} \mathrm{NPs}$ on $\mathrm{Si}$ & $(61 / 900) / 1-2$ & Rhodamine 6G & {$[101]$} \\
\hline $\mathrm{Au} @ \mathrm{SiO}_{2} \mathrm{NPs}$ on $\mathrm{TiO}_{2}(h k l)$ & $55 / 2$ & Photoinduced behavior of dyes & {$[102]$} \\
\hline $\mathrm{Ag} @ \mathrm{SiO}_{2} \mathrm{NPs}$ on filter paper & $45 / 3$ & Thiram & [103] \\
\hline $\mathrm{Ag} @ \mathrm{TiO}_{2} \mathrm{NPs}$ & $10-30 / 2-10$ & Copper ions & {$[104]$} \\
\hline $\mathrm{Ag} @ \mathrm{TiO}_{2} \mathrm{NPs}$ & $20 / 2-10$ & Copper oxidation states & {$[105]$} \\
\hline cc-Au@Ag@SiO ${ }_{2}$ NPs & $50 / 4 / 2-5$ & 4-mercaptobenzoic acid & [106] \\
\hline Au@PPy bipyramids & 100 (length)/1 & $\gamma$-aminobutyric acid & [108] \\
\hline $\mathrm{Au} @ \mathrm{SiO}_{2} \mathrm{NPs}$ & $40 / 5$ & Metschnikowia pulcherrima yeast cells & [109] \\
\hline $\mathrm{Au} @ \mathrm{SiO}_{2} \mathrm{NPs}$ & $55 / 2$ & Atypical hyperplasia & {$[110]$} \\
\hline $\mathrm{Ag} @ \mathrm{SiO}_{2} \mathrm{NPs}$ & $53 / 2-5$ & Tumor cells in blood & [107] \\
\hline
\end{tabular}

Wondergem et al. have reported the detection of Rhodamine 6G (R6G) molecules by SHINERS spectroscopy [101]. For SHINERS experiments, $\left(\mathrm{Au} / \mathrm{SiO}_{2}\right) @ \mathrm{SiO}_{2}$ nanoparticles were used in order to avoid contact between gold nanoparticles and the liquid medium. The authors have obtained a detection limit of $10^{-12} \mathrm{M}$ for R6G molecules with these $\left(\mathrm{Au} / \mathrm{SiO}_{2}\right) @ \mathrm{SiO}_{2}$ plasmonic superstructures. Moreover, these plasmonic superstructures can enable the study of catalytic reactions in liquids by using SHINERS [101]. In addition, Zhang et al. have investigated the photoinduced behavior of dyes (N719) molecules on three rutile $\mathrm{TiO}_{2}(h k l)$ surfaces [102]. Au@SiO 2 nanoparticles were employed for SHINERS experiments. The authors have remarked that the SCN group of N719 molecules was the group that primarily adsorbed on these three rutile $\mathrm{TiO}_{2}(h k l)$ surfaces. The authors have evidenced a shift of the Raman peak corresponding to the SCN group after an illumination time of 36 min on $\mathrm{TiO}_{2}(110)$ and $\mathrm{TiO}_{2}(001)$ surfaces, whereas no shift of this Raman peak was observed for the $\mathrm{TiO}_{2}$ (111) surface. They concluded that the N719 molecules adsorbed on $\mathrm{TiO}_{2}(111)$ surface were very stable in the time, whereas the N719 molecules had desorbed on $\mathrm{TiO}_{2}(110)$ and $\mathrm{TiO}_{2}(001)$ surfaces caused by the cleavage of the $\mathrm{S}=\mathrm{C}$ binding [102]. Furthermore, Sun et al., have reported a detection limit of $10^{-9} \mathrm{M}$ for thiram 
molecules (pesticides) probed by the SHINERS spectroscopy [103]. Ag@SiO ${ }_{2}$ nanoparticles on filter paper were employed as well as a miniaturized portable Raman analyzer based on smart-phone for SHINERS experiments. The authors have recorded SHINERS spectra for each concentration of thiram molecules (concentration range $=10^{-9}-10^{-3} \mathrm{M}$ ), where four characteristic Raman peaks of thiram molecules located at 440,559, 1145 and $1379 \mathrm{~cm}^{-1}$ are displayed (see Figure 7). By using the Raman peak at $1379 \mathrm{~cm}^{-1}$, the authors have deduced the detection limit (see Figure 7).

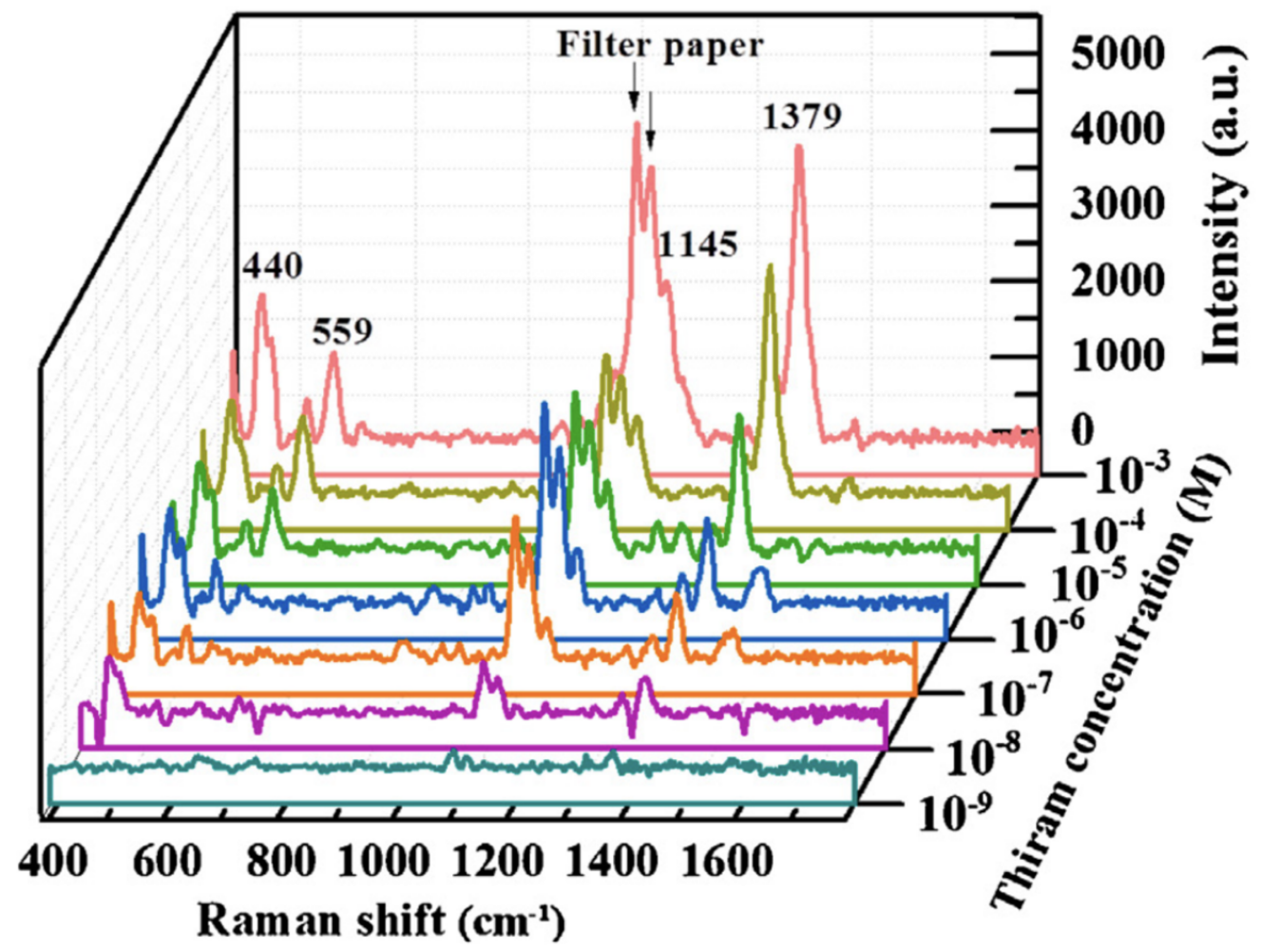

Figure 7. SHINERS spectra of thiram recorded for various concentrations in the range $10^{-9}-10^{-3} \mathrm{M}$, where are indicated the four characteristic Raman peaks as well as the two peaks associated to the filter paper. The figure is reprinted from [103], Copyright 2019, with permission from Elsevier.

In the next two works realized by the same group [104,105], the detection of copper ions and their oxidation states by SHINERS is addressed. Firstly, Forato et al., have investigated the detection of $\mathrm{Cu}(\mathrm{II})$ ions by SHINERS spectroscopy. Ag@ $@ \mathrm{TiO}_{2}$ nanoparticles and three excitation wavelengths $(514,633$, and $785 \mathrm{~nm})$ were used for SHINERS experiments. The authors have demonstrated an optimal efficiency for the detection of the Raman peak of the $\mathrm{Cu}-\mathrm{N}$ binding at an excitation wavelength of $633 \mathrm{~nm}$ [104]. Then, Quéffelec et al., have reported on the distinctness of $\mathrm{Cu}(\mathrm{I})$ and $\mathrm{Cu}(\mathrm{II})$ ions by SHINERS measurements [105]. The authors have used the same $\mathrm{Ag} @ \mathrm{TiO}_{2}$ nanoparticles functionalized with 2,2'-bipyridine phosphonate (bpy-PA) and an excitation wavelength of $633 \mathrm{~nm}$ where the efficiency was optimal [104]. From the SHINERS spectra recorded for $\mathrm{Ag} @ \mathrm{TiO}_{2} @ \mathrm{bpy}-\mathrm{PA}, \mathrm{Ag} @ \mathrm{TiO}_{2} @ \mathrm{bpy}-$ PA-Cu(I) and Ag@TiO $@$ @by-PA-Cu(II), the authors have detected the characteristic Raman peaks of $\mathrm{N}-\mathrm{Cu}(\mathrm{II})$ and $\mathrm{N}-\mathrm{Cu}(\mathrm{I})$ vibrational modes at 230 and $290 \mathrm{~cm}^{-1}$, respectively (see Figure 8). 


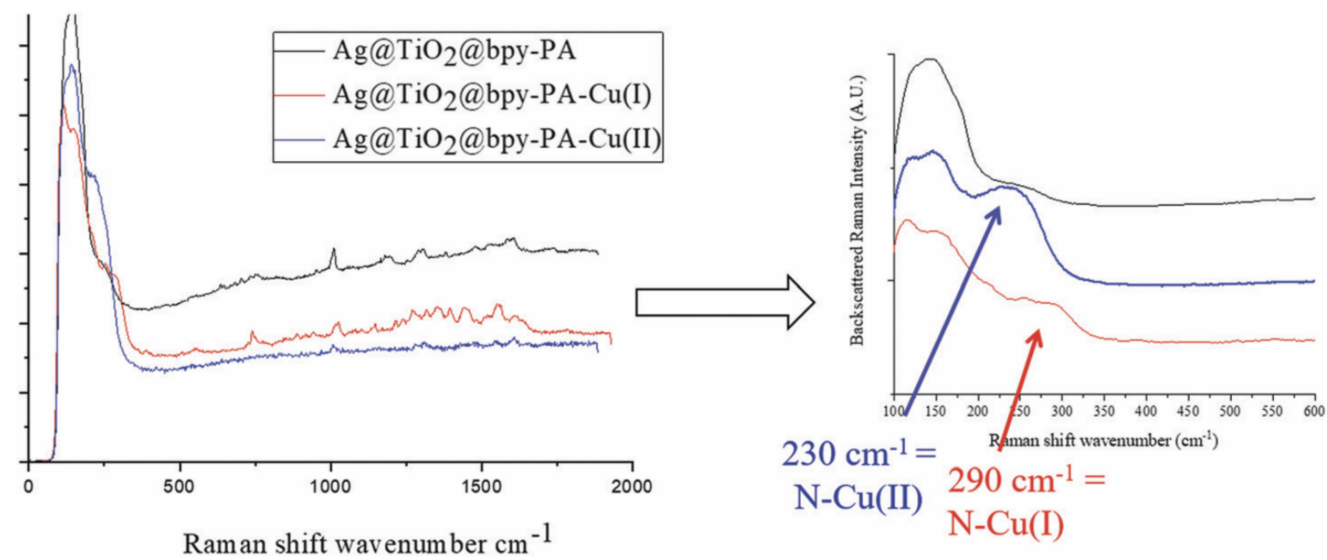

Figure 8. SHINERS spectra for $\mathrm{Ag} @ \mathrm{TiO}_{2} @ b p y-\mathrm{PA}$ (in black), $\mathrm{Ag} @ \mathrm{TiO}_{2} @ b p y-\mathrm{PA}-\mathrm{Cu}(\mathrm{I})$ (in red) and $\mathrm{Ag} @ \mathrm{TiO}_{2} @$ bpy-PA-Cu(II) (in blue), where the Raman peaks of $\mathrm{N}-\mathrm{Cu}(\mathrm{II})$ and $\mathrm{N}-\mathrm{Cu}(\mathrm{I})$ vibrational modes are depicted. The figure is reproduced from [105] with permission from the Royal Society of Chemistry, Copyright 2020.

Krajczewski et al., have reported the detection of four-mercaptobenzoic acid (p-MBA) by SHINERS measurements [106]. Au@Ag concave cubic nanoparticles (noted: cc-Au@Ag NPs) were employed for the p-MBA detection probed by SHINERS measurements. The authors have demonstrated that these cc-Au@Ag NPs have improved by 35\% the enhancement factor of the Raman signal of p-MBA molecules compared to the cc-Au NPs without the thin $\mathrm{Ag}$ shell. Moreover, the authors have added a thin layer of $\mathrm{SiO}_{2}(<5 \mathrm{~nm})$ on cc-Au@Ag NPs, and they recorded a reduction by $50 \%$ of the Raman signal of p-MBA molecules [106]. El-Said et al., have demonstrated the detection of neurotransmitters, such as $\gamma$-aminobutyric acid (GABA), by using the SHINERS technique [108]. Au@PPy nanobipyramids were used for this investigation, and allowed the detection of GABA with high sensitivity (detection limit of $116 \mathrm{nM}$ ). Moreover, these Au@PPy nanobipyramids have also enabled the detection of GABA in the presence of human serum, representing a real sample [108]. Zdaniauskiene et al., have used the SHINERS technique in order to study Metschnikowia pulcherrima yeast cells [109]. $\mathrm{Au} @ \mathrm{SiO}_{2}$ nanoparticles were employed for this investigation, and allowed to obtain SHINERS spectra more enhanced than SERS spectra. Moreover, the $\mathrm{Au} @ \mathrm{SiO}_{2}$ nanoparticles also allowed to suppress the appearance of supplementary bands due to potential interactions with the gold nanoparticles, and to identify the wall of yeast cells and their functional elements [109]. To conclude this section and also this review, two works related to cancer research, focusing on the identification of the atypical hyperplasia $(\mathrm{AH})$ of the breast and the detection of tumor cells, are addressed. Zheng et al., have explored the identification of the breast AH by employing the SHINERS technique, which can provide a non-invasive diagnosis and study the cancer mechanisms at a molecular level [110]. The authors have remarked via changes in the Raman band intensities from SHINERS spectra that DNA strands have begun to snap in breast AH, and the presence of amino acid residues was more important than in normal breast tissues [110]. Nicinski et al., have reported on the improvement of the detection sensitivity of tumor cells such as renal cell carcinoma, and blood cells. This improvement was achieved by using $\mathrm{Ag} @ \mathrm{SiO}_{2}$ nanoparticles via SHINERS measurements. The authors have observed variations in the intensities of Raman bands between cancer and healthy cells due to changes in the structure and quantity of molecules present during the formation of cancer cells [107].

\section{Discussions and Future Directions}

The shell-isolated nanoparticle-enhanced Raman spectroscopy has been generally employed with core-shell nanoparticles composed of gold cores (or silver) and silica shells, because the gold or silver cores presented a strong SERS activity. It would be interesting to use other well-known plasmonic materials, such as aluminum, copper, pal- 
ladium, and other alternative plasmonic materials (e.g., transparent conductive oxides and transition-metal nitrides) in order to study the influence of the nature of plasmonic material on the efficiency of the SHINERS technique to be analyzed different surface reactions at normal and high temperatures. Other materials for the shell fabrication, such as polymers, can be used to investigate the effect of shell material on this same efficiency cited previously. Through the three sections presented above, we have observed that the shell-isolated nanoparticle-enhanced Raman spectroscopy was non-invasive thanks to the catalytically inactive dielectric shell, and also had other advantages, such as the study of different surface catalytic reactions or adsorption of reactants on several surfaces of different natures and morphologies, and the detection of different molecules. Both these studies [84] were realized under normal conditions of temperature $\left(T=20-150{ }^{\circ} \mathrm{C}\right)$ and pressure. However, a great number of catalytic reactions are produced at high temperatures $\left(\mathrm{T}=300-1000^{\circ} \mathrm{C}\right)$ typically in industry. Thus, the thermal stability of SHINERS substrates should be improved for industrial applications. Moreover, the influence of high pressures on the stability of SHINERS substrates is still a research issue to be solved. Another challenging improvement to be addressed is to reduce the shell thickness $(<1 \mathrm{~nm}$; without pinhole in shell) in order to achieve a better Raman enhancement. Besides, another advantage would be to use the shell-isolated nanoparticle-enhanced Raman spectroscopy in catalysis as local nanosensors of molecules during the catalytic reactions in order to have a deep understanding of these catalytic reactions at the subnanometer scale [111]. Furthermore, the shell-isolated nanoparticle-enhanced Raman spectroscopy can be extended to other enhanced spectroscopies as tip-enhanced Raman spectroscopy (named shell-isolated TERS) [112] and sum-frequency generation spectroscopy (named SHINESFG) [113]. The shell-isolated TERS can allow the exclusion of interferences which are due to the presence of contaminants, and also the investigation of catalytic reactions at the level of a solid-liquid interface [112]. To finish, the SHINE-SFG spectroscopy can enable a novel type of enhancement coming from the non-linear coupling of SHINE-SFG with difference frequency generation. Thus, alternative substrates based on this type of coupling can be designed in order to enhance different signals [113].

\section{Conclusions}

In this mini-review, we addressed the applications of the shell-isolated nanoparticleenhanced Raman spectroscopy. We started with the SHINERS application to the reactions with $\mathrm{CO}$ molecules. The reactions of oxidation, hydrogenation, and adsorption of $\mathrm{CO}$ molecules with various catalysts have been presented. Next, we explored SHINERS studies on other surface catalytic reactions. Among these reactions, we presented a couple of works on oxygen reduction reactions realized on $\mathrm{Pt}(h k l)$ surfaces. Then, oxidation reactions of water and $\mathrm{Cu}$ surfaces have been exposed. Hydrogenation and photodegradation reactions, molecule adsorption, and corrosion have been also addressed. Finally, we reported on the detection of molecules and ions by SHINERS spectroscopy. The SHINERS experiments have enabled to improve the detection sensitivity of pesticides (thiram), tumor cells, and to distinguish the copper oxidation states. In conclusion, the shell-isolated nanoparticle-enhanced Raman spectroscopy can be very useful for obtaining various information on surface catalytic reactions, such as their mechanism and the intermediate species present during these reactions. Moreover, the SHINERS substrates based on coreshell nanoparticles can be employed as very sensitive nanosensors of molecules and ions.

Funding: This research received no external funding.

Conflicts of Interest: The author declares no conflict of interest. 


\section{References}

1. Castro-Grijalba, A.; Montes-Garcia, V.; Cordero-Ferradas, M.J.; Coronado, E.; Perez-Juste, J.; Pastoriza-Santos, I. SERS-Based Molecularly Imprinted Plasmonic Sensor for Highly Sensitive PAH Detection. ACS Sens. 2020, 5, 693-702. [CrossRef]

2. Blanco-Formoso, M.; Pazos-Perez, N.; Alvarez-Puebla, R.A. Fabrication and SERS properties of complex and organized nanoparticle plasmonic clusters stable in solution. Nanoscale 2020, 12, 14948-14956. [CrossRef]

3. Lan, L.; Fan, X.; Gao, Y.; Li, G.; Hao, Q.; Qiu, T. Plasmonic metal carbide SERS chips. J. Mater. Chem. C 2020, 8, 14523-14530. [CrossRef]

4. Huang, J.A.; Mousavi, M.Z.; Zhao, Y.Q.; Hubarevich, A.; Omeis, F.; Giovannini, G.; Schutte, M.; Garoli, D.; De Angelis, F. SERS discrimination of single DNA bases in single oligonucleotides by electro-plasmonic trapping. Nat. Commun. 2019, $10,5321$. [CrossRef] [PubMed]

5. Yang, L.T.; Lee, J.H.; Rathnam, C.; Hou, Y.N.; Choi, J.W.; Lee, K.B. Dual-Enhanced Raman Scattering-Based Characterization of Stem Cell Differentiation Using Graphene-Plasmonic Hybrid Nanoarray. Nano Lett. 2019, 19, 8138-8148. [CrossRef] [PubMed]

6. Zhong, J.H.; Vogelsang, J.; Yi, J.M.; Wang, D.; Wittenbecher, L.; Mikaelsson, S.; Korte, A.; Chimeh, A.; Arnold, C.L.; Schaaf, P.; et al. Nonlinear plasmon-exciton coupling enhances sum-frequency generation from a hybrid metal/semiconductor nanostructure. Nat. Commun. 2020, 11, 1464. [CrossRef] [PubMed]

7. Gao, M.; He, Y.H.; Chen, Y.; Shih, T.M.; Yang, W.M.; Chen, H.Y.; Yang, Z.L.; Wang, Z.H. Enhanced sum frequency generation for ultrasensitive characterization of plasmonic modes. Nanophotonics 2020, 9, 815-822. [CrossRef]

8. Dalstein, L.; Humbert, C.; Ben Haddada, M.; Boujday, S.; Barbillon, G.; Busson, B. The Prevailing Role of Hotspots in PlasmonEnhanced Sum-Frequency Generation Spectroscopy. J. Phys. Chem. Lett. 2019, 10, 7706-7711. [CrossRef] [PubMed]

9. Barbillon, G.; Noblet, T.; Busson, B.; Tadjeddine, A.; Humbert, C. Localised detection of thiophenol with gold nanotriangles highly structured as honeycombs by nonlinear sum frequency generation spectroscopy. J. Mater. Sci. 2018, 53, 4554-4562. [CrossRef]

10. Dalstein, L.; Ben Haddada, M.; Barbillon, G.; Humbert, C.; Tadjeddine, A.; Boujday, S.; Busson, B. Revealing the Interplay between Adsorbed Molecular Layers and Gold Nanoparticles by Linear and Nonlinear Optical Properties. J. Phys. Chem. C 2015, 115, 17146-17155. [CrossRef]

11. Ma, W.; Sun, M.; Xu, L.; Wang, L.; Kuang, H.; Xu, C. A SERS active gold nanostar dimer for mercury ion detection. Chem. Commun. 2013, 49, 4989-4991. [CrossRef] [PubMed]

12. Kessentini, S.; Barchiesi, D.; D’Andrea, C.; Toma, A.; Guillot, N.; Di Fabrizio, E.; Fazio, B.; Marago, O.M.; Gucciardi, P.G.; Lamy de la Chapelle, M. Gold Dimer Nanoantenna with Slanted Gap for Tunable LSPR and Improved SERS. J. Phys. Chem. C 2014, 118, 3209-3219. [CrossRef]

13. Hakonen, A.; Svedendahl, M.; Ogier, R.; Yang, Z.-Y.; Lodewijks, K.; Verre, R.; Shegai, T.; Andersson, P.O.; Käll, M. Dimer-on-mirror SERS substrates with attogram sensitivity fabricated by colloidal lithography. Nanoscale 2015, 7, 9405-9410. [CrossRef] [PubMed]

14. Prinz, J.; Heck, C.; Ellerik, L.; Merk, V.; Bald, I. DNA origami based Au-Ag-core-shell nanoparticle dimers with single-molecule SERS sensitivity. Nanoscale 2016, 8, 5612-5620. [CrossRef]

15. Ghosh, P.; Paria, D.; Balasubramanian, K.; Ghosh, A.; Narayanan, R.; Raghavan, S. Directed Microwave-Assisted Self-Assembly of Au-Graphene-Au Plasmonic Dimers for SERS Applications. Adv. Mater. Interfaces 2019, 6, 1900629. [CrossRef]

16. Ma, L.; Wang, J.; Ren, C.; Ju, P.; Huang, Y.; Zhang, F.; Zhao, F.; Zhang, Z.; Zhang, D. Detection of corrosion inhibitor adsorption via a surface-enhanced Raman spectroscopy (SERS) silver nanorods tape sensor. Sens. Actuators B 2020, 321, 128617. [CrossRef]

17. Kuttner, C.; Höller, R.P.M.; Quintanilla, M.; Schnepf, M.J.; Dulle, M.; Fery, A.; Liz-Marzan, L.M. SERS and plasmonic heating efficiency from anisotropic core/satellite superstructures. Nanoscale 2019, 11, 19561-19570. [CrossRef]

18. Reguera, J.; Langer, J.; Jimenez de Aberasturi, D.; Liz-Marzan, L.M. Anistropic metal nanoparticles for surface enhanced Raman scattering. Chem. Soc. Rev. 2017, 46, 3866-3885. [CrossRef]

19. Tang, L.; Li, S.; Han, F.; Liu, L.; Xu, L.; Ma, W.; Kuang, H.; Li, A.; Wang, L.; Xu, C. SERS-active Au@Ag nanorod dimers for ultrasensitive dopamine detection. Biosens. Bioelectron. 2015, 71, 7-12. [CrossRef]

20. Alexander, K.D.; Skinner, K.; Zhang, S.; Wei, H.; Lopez, R. Tunable SERS in Gold Nanorod Dimers through Strain Control on an Elastomeric Substrate. Nano Lett. 2010, 10, 4488-4493. [CrossRef] [PubMed]

21. Höller, R.P.M.; Kuttner, C.; Mayer, M.; Wang, R.; Dulle, M.; Contreras-Caceres, R.; Fery, A.; Liz-Marzan, L.M. Colloidal Superstructures with Triangular Cores: Size Effects on SERS Efficiency. ACS Photonics 2020, 7, 1839-1848. [CrossRef]

22. Koetz, J. The Effect of Surface Modification of Gold Nanotriangles for Surface-Enhanced Raman Scattering Performance. Nanomaterials 2020, 10, 2187. [CrossRef] [PubMed]

23. Liebig, F.; Sarhan, R.M.; Bargheer, M.; Schmitt, C.N.Z.; Poghasyan, A.H.; Shahinsyan, A.A.; Koetz, J. Spiked gold nanotriangles: Formation, characterization and applications in surface-enhanced Raman spectroscopy and plasmon-enhanced catalysis. RSC Adv. 2020, 10, 8152-8160. [CrossRef]

24. Kuttner, C.; Mayer, M.; Dulle, M.; Moscoso, A.; Lopez-Romero, J.M.; Forster, S.; Fery, A.; Perez-Juste, J.; Contreras-Caceres, R. Seeded Growth Synthesis of Gold Nanotriangles: Size Control, SAXS Analysis, and SERS Performance. ACS Appl. Mater. Interfaces 2018, 10, 11152-11163. [CrossRef] [PubMed]

25. Bryche, J.-F.; Tsigara, A.; Bélier, B.; Lamy de la Chapelle, M.; Canva, M.; Bartenlian, B.; Barbillon, G. Surface enhanced Raman scattering improvement of gold triangular nanoprisms by a gold reflective underlayer for chemical sensing. Sens. Actuators $B$ 2016, 228, 31-35. [CrossRef] 
26. Su, Q.; Ma, X.; Dong, J.; Jiang, C.; Qian, W. A Reproducible SERS Substrate Based on Electrostatically Assisted APTESFunctionalized Self-Assembly of Gold Nanostars. ACS Appl. Mater. Interfaces 2011, 3, 1873-1879. [CrossRef]

27. Wang, Y.; Polavarapu, L.; Liz-Marzan, L.M. Reduced Graphene Oxide-Supported Gold Nanostars for Improved SERS Sensing and Drug Delivery. ACS Appl. Mater. Interfaces 2014, 6, 21798-21805. [CrossRef]

28. Indrasekara, A.S.D.S.; Meyers, S.; Shubeita, S.; Feldman, L.C.; Gustafsson, T.; Fabris, L. Gold nanostar substrates for SERS-based chemical sensing in the femtomolar regime. Nanoscale 2014, 6, 8891-8899. [CrossRef]

29. Jimenez de Aberasturi, D.; Serrano-Montes, A.B.; Langer, J.; Henriksen-Lacey, M.; Parak, W.J.; Liz-Marzan, L.M. Surface enhanced Raman scattering encoded gold nanostars for multiplexed cell discrimination. Chem. Mater. 2016, 28, 6779-6790. [CrossRef]

30. Serrano-Montes, A.B.; Langer, J.; Henriksen-Lacey, M.; Jimenez de Aberasturi, D.; Solis, D.M.; Taboada, J.M.; Obelleiro, F.; Sentosun, K.; Bals, S.; Bekdemir, A.; et al. Gold nanostar-coated polystyrene beads as multifunctional nanoprobes for SERS bioimaging. J. Phys. Chem. C 2016, 120, 20860-20868. [CrossRef]

31. Zhang, L.; Lang, X.; Hirata, A.; Chen, M. Wrinkled Nanoporous Gold Films with Ultrahigh Surface-Enhanced Raman Scattering Enhancement. ACS Nano 2011, 5, 4407-4413. [CrossRef] [PubMed]

32. Zhang, X.; Zheng, Y.; Liu, X.; Lu, W.; Dai, J.; Lei, D.; MacFarlane, D.R. Hierarchical Porous Plasmonic Metamaterials for Reproducible Ultrasensitive Surface-Enhanced Raman Spectroscopy. Adv. Mater. 2015, 27, 1090-1096. [CrossRef]

33. Hubarevich, A.; Huang, J.-A.; Giovanni, G.; Schirato, A.; Zhao, Y.; Maccaferri, N.; De Angelis, F.; Alabastri, A.; Garoli, D. $\lambda$-DNA through Porous Materials-Surface-Enhanced Raman Scattering in a Single Plasmonic Nanopore. J. Phys. Chem. C 2020, 124, 22663-22670. [CrossRef]

34. Cao, J.; Liu, H.-L.; Yang, J.-M.; Li, Z.-Q.; Yang, D.-R.; Ji, L.-N.; Wang, K.; Xia, X.-H. SERS Detection of Nucleobases in Single Silver Plasmonic Nanopores. ACS Sens. 2020, 5, 2198-2204. [CrossRef]

35. Lum, W.; Bruzas, I.; Gorunmez, Z.; Unser, S.; Beck, T.; Sagle, L. Novel Liposome-Based Surface-Enhanced Raman Spectroscopy (SERS) Substrate. J. Phys. Chem. Lett. 2017, 8, 2639-2646. [CrossRef]

36. Yue, W.; Wang, Z.; Whittaker, J.; Lopez-Royo, F.; Yang, Y.; Zayats, A.V. Amplification of surface-enhanced Raman scattering due to substrate-mediated localized surface plasmons in gold nanodimers. J. Mater. Chem. C 2017, 5, 4075-4084. [CrossRef]

37. Benz, F.; Chikkaraddy, R.; Salmon, A.; Ohadi, H.; de Nijs, B.; Mertens, J.; Carnegie, C.; Bowman, R.W.; Baumberg, J.J. SERS of Individual Nanoparticles on a Mirror: Size Does Matter, but so Does Shape. J. Phys. Chem. Lett. 2016, 7, 2264-2269. [CrossRef] [PubMed]

38. Huang, Y.; Ma, L.; Hou, M.; Li, J.; Xie, Z.; Zhang, Z. Hybridized plasmon modes and near-field enhancement of metallic nanoparticle-dimer on a mirror. Sci. Rep. 2016, 6, 30011. [CrossRef]

39. Sobhani, A.; Manjavacas, A.; Cao, Y.; McClain, M.J.; Javier Garcia de Abajo, F.; Nordlander, P.; Halas, N.J. Pronounced Linewidth Narrowing of an Aluminum Nanoparticle Plasmon Resonance by Interaction with an Aluminum Metallic Film. Nano Lett. 2015, 15, 6946-6951. [CrossRef] [PubMed]

40. Convertino, A.; Mussi, V.; Maiolo, L. Disordered array of Au covered silicon nanowires for SERS biosensing combined with electrochemical detection. Sci. Rep. 2016, 6, 25099. [CrossRef]

41. Wang, H.; Jiang, X.; Lee, S.T.; He, Y. Silicon nanohybrid-based surface-enhanced Raman scattering sensors. Small 2014, 10, 4455-4468. [CrossRef]

42. Akin, M.S.; Yilmaz, M.; Babur, E.; Ozdemur, B.; Erdogan, H.; Tamer, U.; Demirel, G. Large area uniform deposition of silver nanoparticles through bio-inspired polydopamine coating on silicon nanowire arrays for practical SERS applications. J. Mater. Chem. B 2014, 10, 4455-4468. [CrossRef] [PubMed]

43. Bryche, J.-F.; Bélier, B.; Bartenlian, B.; Barbillon, G. Low-cost SERS substrates composed of hybrid nanoskittles for a highly sensitive sensing of chemical molecules. Sens. Actuators B 2017, 239, 795-799. [CrossRef]

44. Barbillon, G.; Ivanov, A.; Sarychev, A.K. Hybrid Au/Si Disk-Shaped Nanoresonators on Gold Film for Amplified SERS Chemical Sensing. Nanomaterials 2019, 9, 1588. [CrossRef]

45. Graniel, O.; Iatsunskyi, I.; Coy, E.; Humbert, C.; Barbillon, G.; Michel, T.; Maurin, D.; Balme, S.; Miele, P.; Bechelany, M. Au-covered hollow urchin-like ZnO nanostructures for surface-enhanced Raman scattering sensing. J. Mater. Chem. C 2019, 7, 15066-15073. [CrossRef]

46. Cui, S.; Dai, Z.; Tian, Q.; Liu, J.; Xiao, X.; Jiang, C.; Wu, W.; Roy, V.A.L. Wetting properties and SERS applications of ZnO/Ag nanowire arrays patterned by a screen printing method. J. Mater. Chem. C 2016, 4, 6371-6379. [CrossRef]

47. Lee, Y.; Lee, J.; Lee, T.K.; Park, J.; Ha, M.; Kwak, S.K.; Ko, H. Particle-on-film gap plasmons on antireflective ZnO nanocone arrays for molecular-level surface-enhanced Raman scattering sensors. ACS Appl. Mater. Interfaces 2015, 7, 26421-26429. [CrossRef]

48. Song, W.; Ji, W.; Vantasin, S.; Tanabe, I.; Zhao, B.; Ozaki, Y. Fabrication of a highly sensitive surface-enhanced Raman scattering substrate for monitoring the catalytic degradation of organic pollutants. J. Mater. Chem. A 2015, 3, 13556-13562. [CrossRef]

49. He, X.; Yue, C.; Zang, Y.; Yin, J.; Sun, S.; Li, J.; Kang, J. Multi-hotspot configuration on urchin-like Ag nanoparticle/ZnO hollow nanosphere arrays for highly sensitive SERS. J. Mater. Chem. A 2013, 1, 15010-15015. [CrossRef]

50. Liu, X.W.; Wang, D.S.; Li, Y.D. Synthesis and catalytic properties of bimetallic nanomaterials with various architectures. Nano Today 2012, 7, 448-466. [CrossRef]

51. Su, Y.; Xu, S.; Zhang, J.; Chen, X.; Jiang, L.-P.; Zheng, T.; Zhu, J.-J. Plasmon Near-Field Coupling of Bimetallic Nanostars and a Hierarchical Bimetallic SERS “Hot Field": Toward Ultrasensitive Simultaneous Detection of Multiple Cardiorenal Syndrome Biomarkers. Anal. Chem. 2019, 91, 864-872. [CrossRef] [PubMed] 
52. Joseph, D.; Kwak, C.H.; Huh, Y.S.; Han, Y.-K. Synthesis of AuAg@Ag core@shell hollow cubic nanostructures as SERS substrates for attomolar chemical sensing. Sens. Actuators B 2019, 281, 471-477. [CrossRef]

53. Vu, T.D.; Duy, P.K.; Chung, H. Nickel foam-caged Ag-Au bimetallic nanostructure as a highly rugged and durable SERS substrate. Sens. Actuators B 2019, 282, 535-540. [CrossRef]

54. Barbillon, G. Latest Novelties on Plasmonic and Non-Plasmonic Nanomaterials for SERS Sensing. Nanomaterials 2020, 10, 1200. [CrossRef]

55. Hussain, A.; Sun, D.-W.; Pu, H. Bimetallic core shelled nanoparticles (Au@AgNPs) for rapid detection of thiram and dicyandiamide contaminants in liquid milk using SERS. Food Chem. 2020, 317, 126429. [CrossRef]

56. Cong, S.; Yuan, Y.; Chen, Z.; Hou, J.; Yang, M.; Su, Y.; Zhang, Y.; Li, L.; Li, Q.; Geng, F.; et al. Noble metal-comparable SERS enhancement from semiconducting metal oxides by making oxygen vacancies. Nat. Commun. 2015, 6, 7800. [CrossRef]

57. Liu, W.; Bai, H.; Li, X.; Li, W.; Zhai, J.; Li, J.; Xi, G. Improved Surface-Enhanced Raman Spectroscopy Sensitivity on Metallic Tungsten Oxide by the Synergistic Effect of Surface Plasmon Resonance Coupling and Charge Transfer. J. Phys. Chem. Lett. 2018, 9, 4096-4100. [CrossRef] [PubMed]

58. Hou, X.; Fan, X.; Wei, P.; Qiu, T. Planar transition metal oxides SERS chips: A general strategy. J. Mater. Chem. C 2019, 7, 11134-11141. [CrossRef]

59. Wei, W.; Yao, Y.; Zhao, Q.; Xu, Z.; Wang, Q.; Zhang, Z.; Gao, Y. Oxygen defect-induced localized surface plasmon resonance at the $\mathrm{WO}_{3-x}$ quantum dot/silver nanowire interface: SERS and photocatalysis. Nanoscale 2019, 11, 5535-5547. [CrossRef]

60. He, R.; Lai, H.; Wang, S.; Chen, T.; Xie, F.; Chen, Q.; Liu, P.; Chen, J.; Xie, W. Few-layered vdW MoO 3 for sensitive, uniform and stable SERS applications. Appl. Surf. Sci. 2020, 507, 145116. [CrossRef]

61. Wang, X.; Li, J.; Shen, Y.; Xie, A. An assembled ordered $\mathrm{W}_{18} \mathrm{O}_{49}$ nanowire film with high SERS sensitivity and stability for the detection of RB. Appl. Surf. Sci. 2020, 504, 144073. [CrossRef]

62. Ben-Jaber, S.; Peveler, W.J.; Quesada-Cabrera, R.; Cortés, E.; Sotelo-Vazquez, C.; Abdul-Karim, N.; Maier, S.A.; Parkin, I.P. Photo-induced enhanced Raman spectroscopy for universal ultra-trace detection of explosives, pollutants and biomolecules. Nat. Commun. 2016, 7, 12189. [CrossRef] [PubMed]

63. Glass, D.; Cortés, E.; Ben-Jaber, S.; Brick, T.; Peveler, W.J.; Blackman, C.S.; Howle, C.R.; Quesada-Cabrera, R.; Parkin, I.P.; Maier, S.A. Dynamics of Photo-Induced Surface Oxygen Vacancies in Metal-Oxide Semiconductors Studied Under Ambient Conditions. Adv. Sci. 2019, 6, 1901841. [CrossRef] [PubMed]

64. Barbillon, G.; Noblet, T.; Humbert, C. Highly crystalline ZnO film decorated with gold nanospheres for PIERS chemical sensing. Phys. Chem. Chem. Phys. 2020, 22, 21000-21004. [CrossRef]

65. Sun, H.H.; Yao, M.G.; Song, Y.P.; Zhu, L.Y.; Dong, J.J.; Liu, R.; Li, P.; Zhao, B.; Liu, B.B. Pressure-induced SERS enhancement in a $\mathrm{MoS}_{2} / \mathrm{Au} / \mathrm{R} 6 \mathrm{G}$ system by a two-step charge transfer process. Nanoscale 2019, 11, 21493-21501. [CrossRef]

66. Barbillon, G. Nanoplasmonics in High Pressure Environment. Photonics 2020, 7, 53. [CrossRef]

67. Li, J.-F.; Huang, Y.F.; Ding, Y.; Yang, Z.L.; Li, S.B.; Zhou, X.S.; Fan, F.R.; Zhang, W.; Zhou, Z.Y.; Wu, D.Y.; et al. Shell-isolated nanoparticle-enhanced Raman spectroscopy. Nature 2010, 464, 392-395. [CrossRef]

68. Ding, S.-Y.; Yi, J.; Li, J.-F.; Ren, B.; Wu, D.-Y.; Panneerselvam, R.; Tian, Z.-Q. Nanostructure-based plasmon-enhanced Raman spectroscopy for surface analysis of materials. Nat. Rev. Mater. 2016, 1, 16021. [CrossRef]

69. Li, J.-F.; Zhang, Y.-J.; Ding, S.-Y.; Panneerselvam, R.; Tian, Z.-Q. Core-Shell Nanoparticle-Enhanced Raman Spectroscopy. Chem. Rev. 2017, 111, 5002-5069. [CrossRef]

70. Li, C.-Y.; Meng, M.; Huang, S.-C.; Li, L.; Huang, S.-R.; Chen, S.; Meng, L.-Y.; Panneerselvam, R.; Zhang, S.-J.; Ren, B.; et al. “Smart” Ag Nanostructures for Plasmon-Enhanced Spectroscopies. J. Am. Chem. Soc. 2015, 137, 13784-13787. [CrossRef] [PubMed]

71. Hartman, T.; Weckhuysen, B.M. Thermally Stable $\mathrm{TiO}_{2}$ - and $\mathrm{SiO}_{2}$-Shell-Isolated Au Nanoparticles for In Situ Plasmon-Enhanced Raman Spectroscopy of Hydrogenation Catalysts. Chem. Eur. J. 2018, 24, 3733-3741. [CrossRef] [PubMed]

72. Hartman, T.; Wondergem, C.S.; Weckhuysen, B.M. Pratical Guidelines for Shell-Isolated Nanoparticle-Enhanced Raman Spectroscopy of Heterogeneous Catalysts. ChemPhysChem 2018, 19, 2461-2467. [CrossRef]

73. Zhang, H.; Zhang, X.G.; Wei, J.; Wang, C.; Chen, S.; Sun, H.L.; Wang, Y.H.; Chen, B.H.; Yang, Z.L.; Wu, D.Y.; et al. Revealing the Role of Interfacial Properties on Catalytic Behaviors by In-Situ Surface-Enhanced Raman Spectroscopy. J. Am. Chem. Soc. 2017, 139, 10339-10346. [CrossRef]

74. Zhang, H.; Wang, C.; Sun, H.L.; Fu, G.; Chen, S.; Zhang, Y.J.; Chen, B.H.; Anema, J.R.; Yang, Z.L.; Li, J.F.; et al. In Situ Dynamic Tracking of Heterogeneous Nanocatalytic Processes by Shell-Isolated Nanoparticle-Enhanced Raman Spectroscopy. Nat. Commun. 2017, 8, 15447. [CrossRef]

75. Lin, X.-D.; Li, J.-F.; Huang, Y.-F.; Tian, X.-D.; Uzayisenga, V.; Li, S.-B.; Ren, B.; Tian, Z.-Q. Shell-isolated nanoparticle-enhanced Raman spectroscopy: Nanoparticle synthesis, characterization and applications in electrochemistry. J. Electroanal. Chem. 2013, 688, 5-11. [CrossRef]

76. Liu, Y.; Hu, Y.; Zhang, J. Few-Layer Graphene-Encapsulated Metal Nanoparticles for Surface-Enhanced Raman Spectroscopy. J. Phys. Chem. C 2014, 118, 8993-8998. [CrossRef]

77. Chen, S.N.; Li, X.; Zhao, Y.Y.; Chang, L.M.; Qi, J.Y. Graphene oxide shell-isolated Ag nanoparticles for surface-enhanced Raman scattering. Carbon 2015, 81, 767-772. [CrossRef]

78. Yang, C.; Zhang, C.; Huo, Y.Y.; Jiang, S.Z.; Qiu, H.W.; Xu, Y.Y.; Li, X.H.; Man, B.Y. Shell-isolated graphene@Cu nanoparticles on graphene@Cu substrates for the application in SERS. Carbon 2016, 98, 526-533. [CrossRef] 
79. Lin, X.-D.; Uzayisenga, V.; Li, J.-F.; Fang, P.-P.; Wu, D.-Y.; Ren, B.; Tian, Z.-Q. Synthesis of ultrathin and compact Au@MnO 2 nanoparticles for shell-isolated nanoparticle-enhanced Raman spectroscopy. J. Raman Spectrosc. 2012, 43, 40-45. [CrossRef]

80. Honesty, N.R.; Gewirth, A.A. Shell-isolated nanoparticle enhanced Raman spectroscopy (SHINERS) investigation of benzotriazole film formation on $\mathrm{Cu}(100), \mathrm{Cu}(111)$, and $\mathrm{Cu}$ (poly). J. Raman Spectrosc. 2012, 43, 46-50. [CrossRef]

81. Li, S.-B.; Li, L.-M.; Anema, J.R.; Li, J.-F.; Yang, Z.-L.; Ren, B.; Sun, J.-J.; Tian, Z.-Q. Shell-Isolated Nanoparticle-Enhanced Raman Spectroscopy (SHINERS) Based on Gold-Core Silica-Shell Nanorods. Z. Phys. Chem. 2011, 225, 775-783. [CrossRef]

82. Wang, Y.-H.; Wei, J.; Radjenovic, P.; Tian, Z.-Q.; Li, J.-F. In Situ Analysis of Surface Catalytic Reactions Using Shell-Isolated Nanoparticle-Enhanced Raman Spectroscopy. Anal. Chem. 2019, 91, 1675-1685. [CrossRef]

83. Su, M.; Dong, J.-C.; Le, J.-B.; Zhao, Y.; Yang, W.-M.; Yang, Z.-L.; Attard, G.; Liu, G.-K.; Cheng, J.; Wei, Y.-M.; et al. In Situ Raman Study of CO Electrooxidation Pt $(\mathrm{Hkl})$ Single-Cryst. Surfaces Acidic Solution. Angew. Chem. Int. Ed. 2020, 59, 1-6. [CrossRef]

84. Wondergem, C.S.; Hartman, T.; Weckhuysen, B.M. In Situ Shell-Isolated Nanoparticle-Enhanced Raman Spectroscopy to Unravel Sequential Hydrogenation of Phenylacetylene over Platinum Nanoparticles. ACS Catal. 2019, 9, 10794-10802. [CrossRef]

85. Wondergem, C.S.; Kromwijk, J.J.G.; Slagter, M.; Vrijburg, W.L.; Hensen, E.J.M.; Monai, M.; Vogt, C.; Weckhuysen, B.M. In Situ Shell-Isolated Nanoparticle-Enhanced Raman Spectroscopy of Nickel-Catalyzed Hydrogenation Reactions. ChemPhysChem 2020, 21, 625-632. [CrossRef]

86. Hartman, T.; Geitenbeek, R.G.; Whiting, G.T.; Weckhuysen, B.M. Operando monitoring of temperature and active species at the single catalyst particle level. Nat. Catal. 2019, 2, 986-996. [CrossRef]

87. Zhang, Y.-J.; Chen, Q.-Q.; Chen, X.; Wang, A.; Tian, Z.-Q.; Li, J.-F. Graphene-coated Au nanoparticle-enhanced Raman spectroscopy. J. Raman Spectrosc. 2020, 1-7. [CrossRef]

88. Kuruvinashetti, K.; Zhang, Y.; Li, J.; Kornienko, N. Shell isolated nanoparticle enhanced Raman spectroscopy for renewable energy electorcatalysis. New J. Chem. 2020, 44, 19953-19960. [CrossRef]

89. Zhao, Y.; Chang, X.; Malkani, A.S.; Yang, X.; Thompson, L.; Jiao, F.; Xu, B. Speciation of Cu Surfaces During the Electrochemical CO Reduction Reaction. J. Am. Chem. Soc. 2020, 142, 9735-9743. [CrossRef]

90. Guan, S.; Attard, G.A.; Wain, A.J. Observation of Substituent Effects in the Electrochemical Adsorption and Hydrogenation of Alkynes on Pt $\{$ Hkl $\}$ Using SHINERS. ACS Catal. 2020, 10, 10999-11010. [CrossRef]

91. Saeed, K.H.; Forster, M.; Li, J.-F.; Hardwick, L.J.; Cowan, A.J. Water oxidation intermediates on iridium oxide electrodes probed by in situ electrochemical SHINERS. Chem. Commun. 2020, 56, 1129-1132. [CrossRef] [PubMed]

92. Li, C.-Y.; Le, J.-B.; Wang, Y.-H.; Chen, S.; Yang, Z.-L.; Li, J.-F.; Cheng, J.; Tian, Z.-Q. In situ probing electrified interfacial water structures at atomically flat surfaces. Nat. Mater. 2019, 18, 697-701. [CrossRef]

93. Guo, B.; Lin, X.; Burgess, I.J.; Yu, C. Electrochemical SHINERS investigation of the adsorption of butyl xanthate and 2mercaptobenzothiazole on pyrite. Appl. Surf. Sci. 2020, 529, 147118. [CrossRef]

94. Bodappa, N.; Su, M.; Zhao, Y.; Le, J.-B.; Yang, W.-M.; Radjenovic, P.; Dong, J.-C.; Cheng, J.; Tian, Z.-Q.; Li, J.-F. Early Stages of Electrochemical Oxydation of $\mathrm{Cu}(111)$ and Polycrystalline Cu Surfaces Revealed by in Situ Raman Spectroscopy. J. Am. Chem. Soc. 2019, 141, 12192-12196. [CrossRef]

95. Galloway, T.A.; Dong, J.-C.; Li, J.-F.; Attard, G.; Hardwick, L.J. Oxygen reactions on Pthkl in a non-aqueous Na+ electrolyte: Site selective stabilisation of a sodium peroxy species. Chem. Sci. 2019, 10, 2956-2964. [CrossRef]

96. Dong, J.-C.; Zhang, X.-G.; Briega-Martos, V.; Jin, X.; Yang, J.; Chen, S.; Yang, Z.-L.; Wu, D.-Y.; Feliu, J.M.; Williams, C.T.; et al. In situ Raman spectroscopic evidence for oxygen reduction reaction intermadiates at platinum single-crystal surfaces. Nat. Energy 2019, 4, 60-67. [CrossRef]

97. Dong, J.-C.; Su, M.; Briega-Martos, V.; Li, L.; Le, J.-B.; Radjenovic, P.; Zhou, X.-S.; Feliu, J.M.; Tian, Z.-Q.; Li, J.-F. Direct in Situ Raman Spectroscopic Evidence of Oxygen Reduction Reaction Intermadiates at High-Index Pt(hkl) Surfaces. J. Am. Chem. Soc. 2020, 142, 715-719. [CrossRef]

98. Barlow, B.C.; Guo, B.; Situm, A.; Grosvenor, A.P.; Burgess, I.J. Shell isolated nanoparticle enhanced Raman spectroscopy (SHINERS) studies of steel surface corrosion. J. Electroanal. Chem. 2019, 853, 113559. [CrossRef]

99. Wang, C.; Chen, X.; Chen, T.-M.; Wei, J.; Qin, S.-N.; Zheng, J.-F.; Zhang, H.; Tian, Z.-Q.; Li, J.-F. In-situ SHINERS Study of the Size and Composition Effect of Pt-Based Nanocatalysts in Catalytic Hydrogenation. ChemCatChem 2020, 12, 75-79. [CrossRef]

100. Qiu, H.; Wang, M.; Zhang, L.; Cao, M.; Yang, Z.; Dou, J.; Ji, S.; Ji, Y.; Kou, S.; Bhatti, A.S. Insights into the role of graphene in hybrid photocatalytic system by in-situ shell-isolated nanoparticle-enhanced Raman Spectroscopy. Carbon 2019, 152, 305-315. [CrossRef]

101. Wondergem, C.S.; van Swieten, T.P.; Geitenbeek, R.G.; Erné, B.H.; Weckhuysen, B.M. Extented Surface-Enhanced Raman Spectroscopy to Liquids Using Shell-Isolated Plasmonic Superstructures. Chem. Eur. J. 2019, 25, 15772-15778. [CrossRef]

102. Zhang, S.-P.; Lin, J.-S.; Lin, R.-K.; Radjenovic, P.M.; Yang, W.-M.; Xu, J.; Dong, J.-C.; Yang, Z.-L.; Hang, W.; Tian, Z.-Q.; et al. In situ Raman study of the photoinduced behavior of dye molecules on $\mathrm{TiO}_{2}(\mathrm{hkl})$ single crystal surfaces. Chem. Sci. 2020, 11, 6431-6435. [CrossRef]

103. Sun, M.; Li, B.; Liu, X.; Chen, J.; Mu, T.; Zhu, L.; Guo, J.; Ma, X. Performance enhancement of paper-based SERS chips by shell-isolated nanoparticle-enhanced Raman spectroscopy. J. Mater. Sci. Technol. 2019, 35, 2207-2212. [CrossRef]

104. Forato, F.; Talebzadeh, S.; Rousseau, N.; Mevellec, J.-Y.; Bujoli, B.; Knight, D.A.; Queffélec, C.; Humbert, B. Functionalized core-shell $\mathrm{Ag} @ \mathrm{TiO}_{2}$ nanoparticles for enhanced Raman spectroscopy: A sensitive detection method for $\mathrm{Cu}$ (II) ions. Phys. Chem. Chem. Phys. 2019, 21, 3066-3072. [CrossRef] [PubMed] 
105. Queffélec, C.; Forato, F.; Bujoli, B.; Knight, D.A.; Fonda, E.; Humbert, B. Investigation of copper oxidation states in plasmonic nanomaterials by XAS and Raman spectroscopy. Phys. Chem. Chem. Phys. 2020, 22, 2193-2199. [CrossRef]

106. Krajczewski, J.; Kedziora, M.; Kołataj, K.; Kudelski, A. Improved synthesis of concave cubic gold nanoparticles and their applications for Raman analysis of surfaces. RSC Adv. 2019, 9, 18609-18618. [CrossRef]

107. Nicinski, K.; Krajczewski, J.; Kudelski, A.; Witkowska, E.; Trzcinska-Danielewicz, J.; Girstun, A.; Kaminska, A. Detection of circulating tumor cells in blood by shell-isolated nanoparticle-Enhanced Raman spectroscopy (SHINERS) in microfluidic device. Sci. Rep. 2019, 9, 9267. [CrossRef]

108. El-Said, W.A.; Alshitari, W.; Choi, J.-W. Controlled fabrication of gold nanobipyramids/polypyrrole for shell-isolated nanoparticleenhanced Raman spectroscopy to detect $\gamma$-aminobutyric acid. Spectrochim. Acta Part A Mol. Biomol. Spectrosc. 2020, 229, 117890. [CrossRef] [PubMed]

109. Zdaniauskienè, A.; Charkova, T.; Ignatjev, I.; Melvydas, V.; Garjonyte,, R.; Matulaitienè, I.; Talaikis, M.; Niaura, G. Shell-isolated nanoparticle-enhanced Raman spectroscopy for characterization of living yeast cells. Spectrochim. Acta Part A Mol. Biomol. Spectrosc. 2020, 240, 118560. [CrossRef]

110. Zheng, C.; Jia, H.Y.; Liu, L.Y.; Wang, Q.; Jiang, H.C.; Teng, L.S.; Geng, C.Z.; Jin, F.; Tang, L.L.; Zhang, J.G.; et al. Molecular fingerprint of precancerous lesions in breast atypical hyperplasia. J. Int. Med. Res. 2020, 48. [CrossRef]

111. Hartman, T.; Geitenbeek, R.G.; Wondergem, C.S.; van der Stam, W.; Weckhuysen, B.M. Operando Nanoscale Sensors in Catalysis: All Eyes on Catalyst Particles. ACS Nano 2020, 14, 3725-3735. [CrossRef] [PubMed]

112. Zhang, H.; Duan, S.; Radjenovic, P.M.; Tian, Z.-Q.; Li, J.-F. Core-Shell Nanostructure-Enhanced Raman Spectroscopy for Surface Catalysis. Acc. Chem. Res. 2020, 53, 729-739. [CrossRef] [PubMed]

113. He, Y.; Ren, H.; You, E.-M.; Radjenovic, P.M.; Sun, S.-G.; Tian, Z.-Q.; Li, J.-F.; Wang, Z. Polarization- and Wavelength-Dependent Shell-Isolated-Nanoparticle-Enhanced Sum-Frequency Generation with High Sensitivity. Phys. Rev. Lett. 2020, $125,047401$. [CrossRef] [PubMed] 